\title{
PROJECT SCHEDULING METHOD WITH TIME USING MRP SYSTEM - A CASE STUDY: CONSTRUCTION PROJECT IN LIBYA
}

\author{
Abdallah Ali Imetieg ${ }^{1, *}$, Miroslav Lutovac ${ }^{2}$ \\ ${ }^{1}$ Singidunum University, Department for Postgraduate Studies, Ph.D Candidate \\ 32 Danijelova Street, Belgrade, Serbia \\ ${ }^{2}$ Singidunum University, Faculty of Tehnical Sciences \\ 32 Danijelova Street, Belgrade, Serbia
}

\begin{abstract}
:
Materials Requirements and Planning (MRP) is a system of production planning and inventory control, which is used to manage manufacturing processes. Most MRP systems are software-based and are used to ensure that the materials are available for production, that the products are available for delivery to customers, that the lowest possible material and product level is maintained in store, as well as to plan delivery schedules and purchasing activities. Upon completion of scheduling, begins the process of follow-up, which includes the achievement of the project goals in terms of quantity, quality and costs in accordance with deadlines. MRP system was applied to project of 5000 housing units in Solug area, which is close to Benghazi city, Libya, with the aim to provide necessary cash flow to pay dues on time without delay to all involved project sub-contractors and material suppliers, to ensure the smooth flow of operations, as well as to diminish costs by reduction of temporary storages and rented areas. There is a correlation between time and cost of each activity. If the required time is shorter than the scheduled time of the certain activity, it would demand more resources, which further leads to the increase in direct costs of the given activity. Therefore, the output of MRP is important since commands are issued through planning in order to launch the suggested orders with the required quantities and within the limited time period.
\end{abstract}

\section{Key words:}

Materials Requirements and Planning (MRP),

cost,

quality,

scheduling process,

project management, Libya.

\section{INTRODUCTION}

Materials Requirement Planning (MRP) refers to production planning, scheduling, and inventory control software systems used to manage manufacturing processes. Namely, it aims to enable the company's management to plan the product parts and control the inflow of these parts to fulfill the service or product within the scheduled time period. MRP is a system that has proven its success within the controlling and planning field on the inventory and production. It has become currently possible to realize the process performance objectives represented in cost mitigation, document submission, high quality, materials and other productive forces of optimal use (Ram, 2006). This system provides a relatively quick, real and effective treatment of scheduling problems, diminishing cost production of orders due to minimum inventory mitigation, time accuracy of materials and parts reception by the working centers whenever they are needed and delivery of orders within the scheduled 
time (Parsaei, 2013). The project implementation of projects has specific characteristics related to their size, complexity and contribution of different parties, including financiers, designers, consultants, contractors, material suppliers, equipment lease, and implementation systems. This matter represents a great challenge for those in charge of the management process and implementation of engineering projects in different fields. The success of any of these projects depends mainly on the existence of effective management that plans, controls activities, correctly conducts timetable for the project and makes necessary procedures to hasten the accomplishment of certain activities in order to accomplish the project within the scheduled time. Certain modern technologies have been selected for the purpose of this research to plan and control construction projects by applying the MRP in order to be implemented on constructing 5000 housing units in the area of Solug, Benghazi, Libya. The paper highlights the increased importance of network analysis studies in project planning at the global level and low inclination culture towards such studies among several researchers in the Arab states including Libya. The researcher's intention to investigate the reasons behind that and the attempt to resolve the given issue have considerably affected the choice of the research topic.

\section{RESEARCH PROBLEM}

The paper deals with the problems of time, cost and optimal exploitation of available resources to achieve the project objectives and meet the required quality standards. In light of this and through the follow-up of implementing 5000 housing units in Solug area, Benghazi, Libya, the problem concerning time evaluation and exploitation of available resources by the company concerned with project implementation was initially observed. Therefore, the researcher deals with this issue using the most common techniques in the operations research, namely MRP, in order to prepare and make the project timetable and control the implementation process.

The research problem lies in the fact that the company concerned with project implementation lacks the project scientific planning method and timetable. This can lead to several unexpected risks which can hinder and block the project implementation or perhaps lead to its termination. This matter requires determining the possible project risk, its sources, various diagnostic methods and the most important strategies that can be adopted to handle the risks. Accordingly, the research problem can be restricted to an essential question of "How can the project be planned and controlled in general, and the study project in particular, by using MRP for the aspects of time and cost and plan the need for materials while reducing the risk rate and fulfilling the required quality?"

\section{RESEARCH HYPOTHESES}

The research is based on the main hypothesis that the multi-tiered global supply-demand network system with its diverse methods (such as MRP) is able to achieve the real level of quality, in the shortest possible time and at the least possible cost, in the implementation of housing units in the area of Solug, Benghazi in Libya.

\section{RESEARCH OBJECTIVES}

The research aims to investigate the impact of Materials Requirements Planning system in reducing the costs of production, procurement, as well as to save time and improve delivery time and service in the project of 5000 housing units in Benghazi, Solug, Libya, in order to achieve the objectives with the least possible time and cost, taking into consideration the required quality.

\section{RESEARCH APPROACH}

The theoretical part of this research relies on the deductive approach. The descriptive analytical technique is used for the purposes of data analysis besides the fieldwork section related to project accomplishment in the area of Solug, Benghazi, Libya. The applied section for project implementation of the research project used the project scheduling method MRP, which is required in all steps and phases of the project. This research focuses on the (Win QSB) program to analyze the MRP project.

\section{DATA COLLECTION SOURCES AND TECHNIQUES}

The research fieldwork depends on the data and information issued by the development department of all administrative centers in Libya, utilities and housing implementation body, the National planning council for housing policies, publications of the public 
information authority. It also relied on the available records and documents about the time and costs of project activities implementation issued by the AlMada Consultative Services Bureau in charge of the engineering supervision. It also depends on the data and information from the Chinese limited company for communication and construction, in charge of the project implementation.

\section{THE CONCEPT OF MATERIAL REQUIREMENT PLANNING SYSTEM}

There are several definitions and concepts that have handled the concept of material needs planning system (Ptak, 2011). Orlicky, who is one of the early system designers, defines MRP as a group of sequencing, integral and logical procedures through designing special restrictions to translate the main production scheduling to the needs of each element of the inventory and identify suitable methods for them.

This system is defined as a group of sequencing, integral and logical procedures to translate the main production scheduling to the component parts of the final product, so that it includes the issuance of purchase or manufacture orders in order to execute main scheduling according to the determined amount and required time (Segerstedt, 1998). The researcher believes that this system is an inventory controlling and production planning software-based technique. It can predict the number of final products with the independent demand in order to define necessary components and required amounts distributed over different time periods. This can be done through identification of the gross and net material needs issued, while taking into consideration the previous inventory review. Based on that review, the amount whose supply order is issued can be increased, reduced, cancelled, deferred or its reception time amended (Gomes da Silva, 2014).

\section{MRP SYSTEM EMERGENCE AND DEVELOPMENT}

MRP is a well-known method of production management whose application heavily realies on computers. This method was proposed in 1965 by Joseph Orlicky and was supported by the American Production and Inventory Control Society in the 1970s. Several amendments and supplements have been made to this system over the last two decades, particularly in relation to the computer ability to process information and the system's increasing use in the service and production processes (Powell, 2012). This system has witnessed three development forms (MRP0, MRP1, and MRP2). The first one (MRP0) is related to the emergence of material needs planning systems in 1960s. The second one (MRP1) indicates that it is a system used to control production and inventory as it is used as an information system to plan and control inventory and productive power (Kassim, 2004; Zaher, 2014). This type scrutinizes the production issued orders to ascertain whether or not there is adequacy of productive power to handle such orders. The third type (MRP2) was developed in 1979 to merge the computation of productive cost and needs planning, and was afterwards renamed into manufacturing resources planning. Thus, MRP2 includes planning of material, financial and human resources and accordingly, the conformity and interaction among different administrative functions (O'Grady, 2012).

\section{MRP SYSTEM OBJECTIVES}

The MRP system aims to reduce the inventory level and cost, improve production scheduling effectiveness and use of materials, as well as to enable quick response to market changes. It helps the production management to accurately identify and state each element of the final product in terms of the required parts and components of identified products in the main production table whose purchase is desired, the purchase required amounts or their production parts, purchase orders issuance or work order of these parts and components to be available when needed.

\section{ADVANTAGES AND DISADVANTAGES OF MRP SYSTEM}

The MRP system output provides suitable information for inventory and production managers (Panizzolo, 2013). It supports the process of inventory planning and controlling through answering the questions related to what, how much, and when to order and when the production should be scheduled and products delivered. It determines the detailed planning of power and required material to meet the requirements of the main production table. It has an effective role in planning the production priority or purchasing according to the planned orders to be launched for the product components and parts. It helps the statistical prediction with product components and preserves inventory to ensure receiving 
materials within the scheduled time. It focuses on long-term material planning, and handles production fluctuations using safety inventory. It is characterized with elasticity as it interacts with demand and plans according to the changing demand. It uses human specialized skills and helps to improve the benefited parties' service in terms of adherence to the scheduled time. It lessens the damage rate in the product subassemblies due to using the correct parts. It is related to a number of other functions including engineering, purchases, finance, sales, accounting, maintenance and distribution.

MRP system has several advantages. Namely, it is a method of planning production without inventory as it preserves the time horizon to produce certain amounts and issue purchase or production according to the scheduled time. It does not require production reorganization, but it allows for the use of available technology (Kim, 2014). One of the most important results that prove its reliability is that it lessens inventory by a rate ranging from $25 \%$ to $40 \%$, mitigates direct production costs by a rate ranging from $5 \%$ to $10 \%$ and mitigates structure costs by $40 \%$ (Wincel, 2013).

In spite of its benefits, the MRP method was severely criticized which reveals its shortages or limitations. Its execution consumes a long period due to qualitative basis and the large size of data, a matter which requires a large database. It assumes unlimited power in all working centers. However, the reality asserts that some working centers may constitute what is called congestion or bottleneck as they cause congestion of the productive process. This may smash the accuracy of which it is characterized to plan production needs of materials and make power planning and control ineffective.

\section{MRP TYPES}

The following are the patterns of the material needs planning system according to the development of the system inputs (Mula, 2006):

- Regenerative approach: according to this approach, needs computations are fully upgraded on a weekly basis in line with the regular time intervals. Therefore, it plans needs of the product parts in terms of quantity and delivery due date. This approach is used when the production cycle is long, manufacture and production occurs in stable environment and when the engineering changes are planned to be reduced to minimum (Rom, 2002).
- Net change approach: according to this technique, part of the planned needs is upgraded after identifying the parts subject to changes related to operating data due to the occurrence of defects or delayed arrival of the produced or purchased materials or their unavailability, without the need to entirely reschedule needs planning. This technique is used when the design change or the engineering changes of the technical structure are repeated, as well as when the operation period for several short products and product design is difficult (Landry, 2013).

Notably, the material needs planning system is a dynamic system. It faces the variables of the industrial environment and processes them using total computation and net computation technique. These variables should not be numerous and tracked in a way that the system cannot assimilate, as this may lead to confusion.

\section{USING MRP SYSTEM FOR SCHEDULING}

Scheduling refers to time order to perform tasks by allocating different production means for each task. It comes after recorded orders management in the main production table in a way that allows to estimate the best term by devising the processes orders for each machine. It works to manage inventory in the best way and within the optimal time period (Sarkar, 2014). After completing the scheduling process, the execution starts with the tracking process that includes achieving a range of production objectives in terms of quantity, quality, terms and costs. The inputs of MRP include main production scheduling, main inventory file and the materials bill. The materials bill means that for each element of the main production scheduling, there is bill of materials. The bill of materials defines all raw materials, components, sub-assemblies and assemblies necessary for element production. The MRP computation system is connected to the file of bill of materials to determine which elements and quantities are required to accomplish a certain element (Zoraghia, 2015). The main inventory file contains detailed information related to the number and quantity of each required, existing element or there is commitment to use it in different time periods. The MRP system is connected to the main inventory computer file to determine the available quantity to be used within the certain time period. The most important MRP outputs are order 
issuances through suggested or planned orders. The scheduling process shows the required quantity of each material within the certain period of time. In addition, there are other reports on changes, exceptions and facilities that constitute outputs. Orders include (Jodlbauer, 2012):

- purchase orders: They refer to the purchase official offer or official order issuance for suppliers to purchase according to certain models issued by the organization including all main data that are related to the required materials such as names, types, standards of each type, required quantity, supply required date agreed upon price, place of supply and the purchase order signed by the purchase manager.

- Work orders or contracts: include issuance of producing the required quantity of the products based on the demand within the specified period of time.

- Planned order report: includes devising a plan of all orders that will be issued in the future. It is a report determining whether the main production scheduling is possible or not. The Figure 1 shows the material needs planning system (Ram, 2006).

\section{MATERIAL AND HUMAN PROJECT REQUIREMENTS}

MRP Process: Starting with end items, the MRP process goes through the following steps:

1. Establish gross requirements.

2. Determine net requirements by subtracting scheduled receipts and on-hand inventory from the gross requirements.

3. Time phase the net requirements.

4. Determine the planned order releases.

The planned order releases aggregated over all the end items will result in the gross requirements for level one item, the gross requirements for these items are then netted and time phased to determine their own order releases. The process continues until all the items have been explored (Jonsson, 2009; Fernandes, 2011).

The project associated with a specific timetable represents the demand for materials needed for the project, and it can be adjusted according to the available capacity. Also, it will depend on the point of suffocation to determine the available capacity of the project at all stages. The suffocation point for the project matches the critical path. Consequently, the yearly and monthly power of the supply chain from materials and manpower are also given in Tables 1-4:

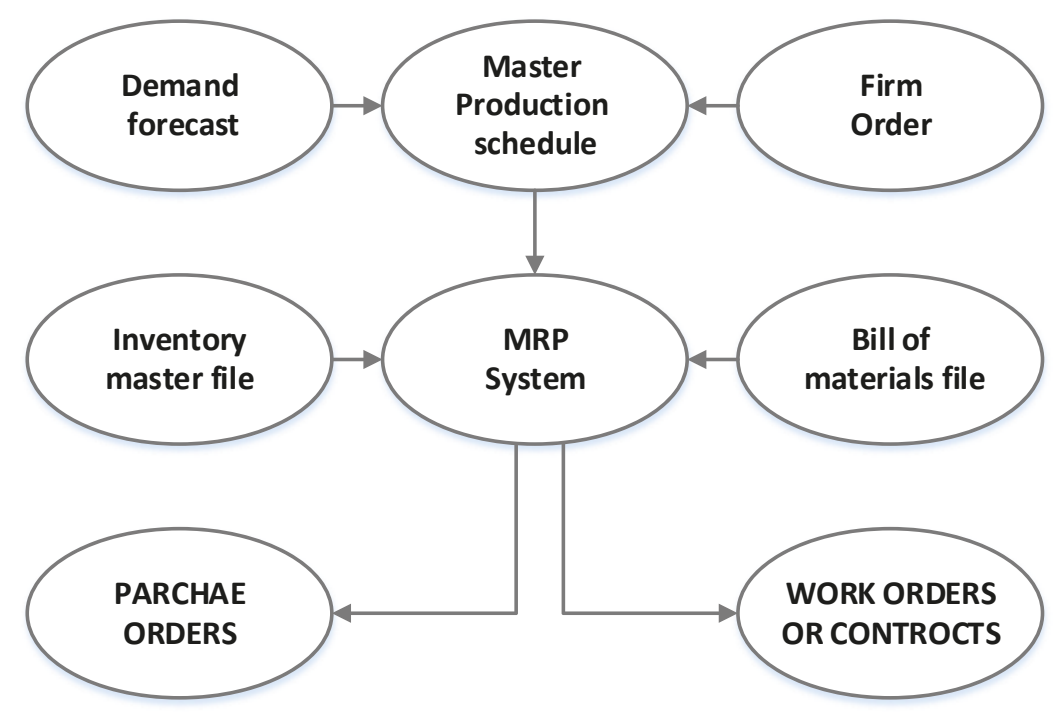

Figure 1. Illustrative model for material requirement planning (MRP) system Source: Benton \& Whybark (2002), p.140 


\begin{tabular}{ccccccc}
\hline Steel type & 2009 & 2010 & 2011 & 2012 & 2013 & Total \\
\hline $18 \mathrm{~mm}$ & 10606 & 10606 & 10606 & 10606 & 10606 & 53032 \\
\hline $16 \mathrm{~mm}$ & 11511 & 11511 & 11511 & 11511 & 11511 & 57559 \\
\hline $14 \mathrm{~mm}$ & 2177 & 2177 & 2177 & 2177 & 2177 & 10888 \\
\hline $12 \mathrm{~mm}$ & 6053 & 6053 & 6053 & 6053 & 6053 & 30265 \\
\hline $10 \mathrm{~mm}$ & 4582 & 4582 & 4582 & 4582 & 4582 & 22912 \\
\hline $8 \mathrm{~mm}$ & 1706 & 1706 & 1706 & 1706 & 1706 & 8534 \\
\hline Total & 36638 & 36638 & 36638 & 36638 & 36638 & 1830193 \\
\hline
\end{tabular}

Table 1. The annual Steel quantity average of a construction and building project of 5000 housing units in the Solug area, Benghazi for the period 2009-2014

Source: Based on the available project data

\begin{tabular}{ccccccc}
\hline Cement type & 2009 & 2010 & 2011 & 2012 & 2013 & Total \\
\hline Sulfate-resistant cement (unpacked) & 57996 & 57996 & 57996 & 57996 & 57996 & 289981 \\
\hline Port-Thai normal cement (unpacked) & 153759 & 153759 & 153759 & 153759 & 153759 & 768796 \\
\hline Port-Thai normal cement (packed) & 64735 & 64735 & 64735 & 64735 & 64735 & 323679 \\
\hline Total & 276491 & 276491 & 276491 & 276491 & 276491 & 13802457 \\
\hline
\end{tabular}

Table 2. The annual Cement quantity average of a construction and building project of 5000 housing units in the Solug area, Benghazi for the period 2009-2014

Source: Based on the available project data

\begin{tabular}{clcccccc}
\hline S/N & \multicolumn{1}{c}{ Description } & Quantity & 2009 & 2010 & 2011 & 2012 & 2013 \\
\hline 1. & Agitating Lorry & 12 & 4 & 2 & 3 & 2 & 1 \\
\hline 2. & Batching Plant & 5 & 2 & 2 & 1 & 0 & 0 \\
\hline 3. & Block Machine & 4 & 2 & 1 & 1 & 0 & 0 \\
\hline 4. & Bulldozer & 3 & 1 & 1 & 1 & 0 & 0 \\
\hline 5. & Diesel Air Compressor & 3 & 2 & 0 & 1 & 0 & 0 \\
\hline 6. & Diesel Emergency Lam & 1 & 1 & 0 & 0 & 0 & 0 \\
\hline 7. & E.Roller & 3 & 2 & 1 & 0 & 0 & 0 \\
\hline 8. & Electrical Generator & 39 & 13 & 10 & 6 & 5 & 5 \\
\hline 9. & Eps Production Line & 1 & 1 & 0 & 0 & 0 & 0 \\
\hline 10. & Excavator & 10 & 4 & 2 & 1 & 2 & 1 \\
\hline 11. & Weigh Bridge & 1 & 1 & 0 & 0 & 0 & 0 \\
\hline$\quad$ Total & 294 & 137 & 58 & 56 & 26 & 17 \\
\hline
\end{tabular}

Table 3. Solug 5000 Housing Units Project, Equipment \& Machinery List

Source: Based on the available project data

\begin{tabular}{lcccccccccccc}
\hline \multicolumn{1}{c}{ Month } & 1 & 2 & 3 & 4 & 5 & 6 & 7 & 8 & 9 & 10 & 11 & 12 \\
\hline Gross requirements & 60 & 75 & 90 & 105 & 110 & 130 & 150 & 120 & 115 & 95 & 80 & 60 \\
\hline Schedule receipts & 50 & 80 & 95 & 140 & 0 & 0 & 0 & 0 & 0 & 0 & 0 & 0 \\
\hline Net requirements & 0 & 0 & 80 & 95 & 120 & 170 & 150 & 130 & 90 & 85 & 70 & 60 \\
\hline Time-phased net req. & 60 & 80 & 90 & 110 & 120 & 135 & 145 & 160 & 145 & 115 & 0 & 0 \\
\hline Planned order releases & 80 & 0 & 0 & 0 & 120 & 75 & 0 & 0 & 40 & 0 & 35 & 0 \\
\hline
\end{tabular}

Table 4. Final MRP Report 


\section{RESEARCH RESULTS AND RECOMMENDATIONS}

- There are reversal relationships between the application of needs planning systems of MRP and timely project accomplishment, at the lowest possible cost and with the required level of quality.

- MRP is a computer-based production programming technique used to enable the company management to plan the product parts and control the inflow of these parts to fulfill the service or product within the scheduled time.

- Materials requirements planning (MRP) system has a significant impact on reducing the costs of production, procurement, as well as saving time and improving delivery time and services in the project.

- The application of material requirements planning (MRP) system in the project management leads to full automation application.

- The MRP inputs consist of Master production schedule, Bill of material (BOM) and inventory status file.

- The MRP helps to determine the material net requirements for the project gross requirements in each time period.

- Besides on-hand data and required materials inventory, as well as the awaiting period for each part and amounts of planned order receipts, the logical procedures of MRP system are also based on master production schedule and project structure and components.

- The MRP system is embodied in the priority planning or purchasing according to planned order release for the project parts and components.

- The number of workers fluctuates during the phases of the project between 2450 and 2640.

- Sudden cease of cement supply as most cement factories in Libya are old. This has led to to machine defects and production suspension, further resulting in cost increase.

In the light of the mentioned findings, the research recommendations are as follows:

- The need for a responsible senior management to supportive material requirements planning (MRP) system due to its high efficiency in the provision of materials in terms of quantity and time.
- Using the bill of materials in calculating the total requirements for each element of the project element starting from the zero-level element.

- Using the bill of materials and the inventory status file to determine the dates, orders and the orders amounts for each element necessary to achieve the project mastering schedule.

- The reproduction of the MRP system on the basis of changes in the project master schedule or the priorities of orders.

- Organizing more training courses for those working in the project management field.

- Optimal exploitation of human power especially when this power is unemployed at some project stages.

\section{CONCLUSION}

The main hypothesis is that the network analysis system Materials Requirements and Planning (MRP) was used to achieve the required level of quality in the shortest time possible and low cost in the implementation of 5000 housing units in the area of Solug, Benghazi in Libya.

To conclude on the outcome of the propositions, the relationship between the time needed to execute the project and the cost is a linear relationship, so that costs can be changed with every proportional change in the period of implementation of each activity. This paper shows that the overall repair process of completion time can be reduced, that it depends on the resources available on time, which can be controlled and planed using computational techniques such as MRP, in order to provide the necessary budget to pay all clients on time.

It is worth noting that the inflation and price rising of materials and services interfere with the process of project accomplishment and rise in the foreign currencies exchange against the Libyan Dinar, which resulted in new financial commitments. However, administration and management may be in the position of trade-off between the savings resulting from the implementation of the project that required less time than it is allocated and the increases in costs arising from the use of additional resources. 


\section{REFERENCES}

Fernandes, F.C.F., \& Filho, M.G. (2011). Production control systems: Literature review, classification, and insights regarding practical application. African Journal of Business Management. 5(14), 5573-5582.

Gomes da Silva, G., \& Maia, C.A. (2014). On just-in-time control of timed event graphs with input constraints: a semimodule approach. Discrete Event Dynamic Systems. DOI: $10.1007 / \mathrm{s} 10626-014-0200-\mathrm{Z}$

Jodlbauer, H., \& Reitner, S. (2012). Material and capacity requirements planning with dynamic lead times. International Journal of Production Research. 50(16), 4477-4492. DOI:10.1080/00207543.2011.603707

Jonsson, P., \& Mattsson, S.A. (2009). Manufacturing, planning and control. New York: McGraw-Hill Higher Education.

Kassim, N. (2004). Application of MRP1 System in the Libyan Public Company for Manufacturing Investments. Journal of Economic Research Benghazi. 15(1), 456.

Khatib, S.M. (2008). The impact of the potential application of the planning system resource requirements to control inventories. MBA, Faculty of Management and Economics, University of Baghdad - Iraq, p. 37

Kim, K. (2014). Material Resource Planning (MRP): Will You Need MRP without the Customer? Open Journal of Social Sciences. 2(4), 1-5. DOI: 10.4236/jss.2014.24027

Landry, S., \& Beaulieu M. (2013). The Challenges of Hospital Supply Chain Management, from Central Stores to Nursing Units, In B. T. Denton (Ed.) Handbook of healthcare operations management: Methods and applications. New York, NY: Springer. 184, 465-482.

Mula, J., Poler, R., Garcia-Sabater, J.P., \& Lario, F.C. (2006). Models for production planning under uncertainty: A review. International Journal of Production Economics. 103 (1), 271-285. DOI:10.1016/j.ijpe.2005.09.001

Obeidi, A.I.H.A. (2007). Adoption of the MRP system in organizational performance improvement using a balanced scorecard technology. BSC-Master technology operations - Management Technical College- Baghdad - Technical Education. p.173

O〉Grady, P.J. (2012). Putting the Just-In-Time Philosophy into Practice: A Strategy for Production Managers. New York. Springer Science \& Business Media.
Panizzolo, R., \& Garengo, P. (2013). Using Theory of Constraints to Control Manufacturing Systems: A Conceptual Model. Industrial Engineering and Management. 3(3), 1-9. DOI: 10.4172/2169-0316.1000111

Parsaei, H.R., Sullivan, W.G., \& Hanley, T.R. (2013). Economic and Financial Justification of Advanced Manufacturing Technologies. Amsterdam: Elsevier.

Powell, D., Alfnes, E., Strandhagen, J.O., \& Dreyer, H., (2012). The concurrent application of lean production and ERP: Towards an ERP-based lean implementation process, Computers in Industry. 64(3), 324-335.

Ptak, C., \& Smith, C. (2011). Orlicky's Material Requirements Planning. New York: McGraw-Hill.

Ram, B., Naghshineh-Pour, M.R., \& Yu, X. (2006). Material requirements planning with flexible bills-of-material. International Journal of Production Research. 44 (2), 399415. DOI: 10.1080/00207540500251505

Rom, W.O., Tukel, O.I., \& Muscatello, J.R. (2002). MRP in a job shop environment using a resource constrained project scheduling model. Omega 30(4), 276. DOI: 10.1016/ S0305-0483(02)00033-6

Sarkar, B., Gupta, H., Chaudhuri, K., Goyal, S.K. (2014). An integrated inventory model with variable lead time, defective units and delay in payments. Applied Mathematics and Computation, 237, 650-658. DOI:10.1016/j. amc.2014.03.061

Segerstedt, A. (1998). Cover-Time Planning: A Less Complex Alternative to MRP. Advanced Models and Methods for Production Planning. Berlin: Springer. DOI: 10.1007/9783-662-03742-3_3

Wincel, J.P., \& Kull, T.J. (2013). People, Process, and Culture: Lean Manufacturing in the Real World. London: CRC Press.

Zaher, H., \& Zaki, T.T. (2014). Optimal Control Theory to Solve Production Inventory System in Supply Chain Management. Journal of Mathematics Research. 6(4), 109-117. DOI: 10.5539/jmr.v6n4p109

Zoraghia, N., Najafib, A.A., \& Niaki, S.T.A. (2014). Resource Constrained Project Scheduling with Material Ordering: Two Hybridized Meta-Heuristic Approaches. International Journal of Engineering. 


\section{METODA PLANIRANJA PROJEKATA U U FUNKCIJI VREMENA KORIŠĆENJEM MRP SISTEMA - STUDIJA SLUČAJA GRAĐEVINSKOG PROJEKTA U LIBIJI}

\section{Rezime:}

Sistemi za planiranje materijalnih potreba preduzeća (MRP) su sistemi koji omogućavaju efektivno planiranje proizvodnje i kontrolu zaliha, a koji se koriste u upravljanju proizvodnim procesima. Većina ovakvih sistema bazira se na softverskim rešenjima. Njihova funkcija jeste da obezbede raspoloživost materijalnih resursa za proizvodnju, dostupnost gotovih proizvoda klijentima, kao i minimalno zadržavanje zaliha u magacinima i radnjama, a sve to za potrebe planiranja rasporeda isporuke i aktivnosti nabavke. Nakon izrade rasporeda slede aktivnosti koje bi trebalo da ispune očekivane projektne ciljeve u smislu količine, kvaliteta i troškova u skladu sa vremenskim rokovima. MRP sistem primenjen je na projektu od 5000 stambenih jedinica u Solug oblasti u blizini grada Bengazi u Libiji, sa ciljem pružanja neophodnog novčanog toka kako bi se isplatili svi podizvođači na projektu bez odlaganja i osiguralo nesmetano poslovanje i izbegli nepotrebni troškovi smanjenjem broja privremenih skladišta i iznajmljenih prostora. Postoji korelacija između vremena i troškova za svaku aktivnost. Naime, ako je potrebno vreme za određenu aktivnost kraće od planiranog, to će zahtevati veću količinu resursa, što dovodi do povećanja direktnih troškova date aktivnosti. Učinak MRP sistema je od velikog značaja zato što se naredbe izdaju kroz planiranje kako bi se pokrenule očekivane nabavke prema zahtevanim količinama u ograničenom vremenu.

\section{Ključne reči:}

Sistemi za planiranje materijalnih potreba preduzeća (MRP), troškovi, kvalitet, raspored, upravljanje projektom, Libija.

Received: February 10, 2015. Correction: March 24, 2015. Accepted: April 15, 2015. 